TITLE:

Leukotriene B4-activated human endothelial cells promote transendothelial neutrophil migration(Abstract_要旨)

AUTHOR(S):

Nohgawa, Masaharu

\title{
CITATION:
}

Nohgawa, Masaharu. Leukotriene B4-activated human endothelial cells promote transendothelial neutrophil migration. 京都大学, 1999, 博士(医学)

ISSUE DATE:

1999-01-25

URL:

http://hdl.handle.net/2433/182276

RIGHT: 


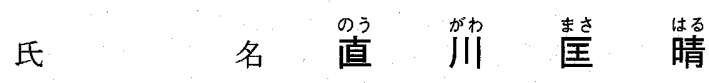

学位 (専攻分野) 博士 士 (医 学)

学位記番号 医 博 第 2061 号

学位授与の日付平成 11 年 1 月 25 日

学位授与の要件学位規則第 4 条第 1 項該当

研究科. 専攻医学研究科内科系専攻

学位論文題目 Leukotriene B4-activated human endothelial cells promote transendothelial neutrophil migration

（ロイコトリエンB4刺激内皮細胞による好中球の血管外遊走誘導）

(主査)

論文調查委員 教授光山正雄教授桂義元教 授 内山卓

\section{論文内容の 要旨}

好中球は生体防御の一次機構において中心的な役割を担っている。この機能を発現するために，好中球が内皮細胞と接着 すること，そして血管外に遊走（transendothelial migration：TEM）することは重要な一過程である。好中球の走化機能 を誘導する因子の一つとして，ロイコトリエンB４（LTB４）がある。LTB４は，アラキドン酸の 5 - リポキシゲナーゼ経 路の代謝物で，さまざまな炎症巣で確認されている。最近，LTB 4 はin vivoおよびin vitroの系で，同じ好中球の遊走因子 であるfMLPに比べ高いTEM活性を誘導することが報告された。この機序を明らかにする目的で，LTB 4 の内皮細胞に対す る直接作用について検討した。

TEM測定にはtranswell（Costar）の膜上にヒト臍帯静脈由来内皮細胞（HUVEC）のmonolayerを作成して用いた。上 層に好中球を加え一定時間後内皮細胞層, filter層を通過し，下層に落下した好中球数を倒立顕微鏡下に算定した。遊走活 性の測定には下層のみに遊走因子を加え, random migrationの測定には上層・下層いずれにも遊走因子を加えた。内皮 細胞を介さない遊走能と random migrationの測定は，アガロース法とマルチチャンバー法によった。

アガロース法とマルチチャンバー法で測定した遊走活性は，fMLPの方が有意に高かった。ところが，TEMによる遊走活 性はLTB 4 の方が有意に高かった。 random migrationについて両者を比較すると，遊走活性と同様にマルチチャンバー法 ではfMLPの方が有意に高く, TEMではLTB 4 の方が有意に高かった。これらの所見は, LTB 4 が内皮細胞に直接作用す ることを示唆した。

HUVECをLTB 4 で前処理し, 洗浄後上層に好中球を添加した時, 未処理では認められなかったTEM活性が強く誘導さ れた。HUVECをLTB 4 で前処理するさらに前にLTB 4 の受容体抗体で処理すると，好中球のTEMは誘導されなかった。 一方LTB4受容体抗体で処理した好中球は，LTB 4 処理HUVECに対して高いTEM活性を示した。これらの所見より，LTB 4 は直接内皮細胞に作用して好中球のTEMを誘導することが確認された。

なおLTB 4 処理HUVECに対する好中球のTEMは，抗ICAM- 1 抗体（84H10）で抑制されたが，LTB 4 はHUVECのICA M- 1 発現に有意な変化を起こさないことがFACSで確認された。

IL- $1 \beta$ やTNF- $\alpha$ がHUVECに作用して，好中球のTEMを誘導することが明らかにされている。この機序として，IL- 8 とPAFの関与が示唆されている。しかし, LTB 4 はIL-8の放出を誘導しなかった。またLTB 4 はHUVECに対して, PAF 放出を誘導しないことが報告されて扬り，LTB 4 による好中球のTEM誘導は，IL- $1 \beta$ やTNF- $\alpha$ とは異なる機序を介する と考えられた。

LTB 4 は種々の炎症性サイトカインの作用により，さまざまな白血球や内皮細胞から産生・放出されることが報告され ている。これまでLTB 4 は遊走因子としてTEMを誘導すること，また内皮細胞に作用して好中球の接着を誘導することが 知られていたが，今回の成績からLTB 4 は，内皮細胞に直接作用してTEMを誘導することが明らかとなった。 


\section{論 文 審 査 の 結 果 の 要 旨}

好中球が血管内から組織に遊出する時, 好中球と内皮細胞の相互作用は重要な一過程である。本研究では, 好中球の走化 因子の一つであるロイコトリエンB 4（LTB 4）が内皮細胞に直接作用し，好中球の遊出を誘導することを明らかにし，ま たその機序についても一部解析した。

好中球の内皮細胞からの遊出（TEM）測定はtrans-well法によった。内皮細胞をLTB 4 で前処理し洗浄後好中球を添加 した時，未処理では認められないTEM活性が誘導された。LTB 4 受容体拮抗剤の内皮細胞並びに好中球に対する効果から， LTB 4 が直接内皮細胞に作用し好中球のTEMを誘導することを確認した。またLTB 4 誘導TEMは，抗ICAM- 1 抗体で抑制 されたが，LTB 4 は内皮細胞のICAM- 1 発現に有意な変化を起こさなかった。IL- $1 \beta$ やTNF- $\alpha$ が内皮細胞に作用して好 中球のTEMを誘導しする機序としてIL- 8 とPAFの関与が報告されている。しかしLTB 4 はIL- 8 の放出を誘導しないこと を確認した。またLTB 4 は内皮細胞に対してPAF放出を誘導しないことが報告されており，LTB 4 による好中球のTEM誘 導は，IL- $1 \beta$ やTNF- $\alpha$ とは機序が異なると考えられた。

本研究は好中球の血管外遊出の機序解明に貢献し，炎症性疾患等の病態解明に寄与するところが多い。

従って，本論文は博士（医学）の学位論文として価値あるものと認める。

なお，本学位授与申請者は平成10年11月25日実施の論文内容とそれに関連した試問を受け，合格と認められたものである。 